\title{
温度依存性を考慮した車両運動解析用タイヤモデルの開発*
}

水 野 雅 彦*1, 酒 井 英 樹*2
大 $山$ 鋼 造*3, 磯 村 吉 高*3

\section{Development of Tire Force Model for Vehicle Dynamics Analysis Including the Effect of Tire Surface Temperature}

\author{
Masahiko MIZUNO*4, Hideki SAKAI, \\ Kozo OYAMA and Yoshitaka ISOMURA \\ ${ }^{* 4}$ CAE Promotion Office. TOYOTA Central R \& D Labs., Inc. \\ Nagakute, Aichi-gun, Aichi, 480-1192 Japan
}

\begin{abstract}
The results of vehicle performance tests often vary depending on differences in the road surface temperature. It is believed that these changes can partially be attributed to the effect of tire surface temperature. The aim of this study is to develop a tire force model considering the dependence of tire surface temperature. The newly developed tire model is composed of two functions, the thermodynamic function that allows us to consider changes in the tire surface temperature and the force function that allows for the effects of tire surface temperature. The parameters of this model are identified using the measured data obtained with an indoor test facility. To prove the validity of the developed model, the surface temperature and the tire force values are predicted using this model. The simulation results agreed rather well with the experimental results.
\end{abstract}

Key Words: Automobile, Modeling, Thermodynamics/Tire, Vehicle Dynamics

\section{1.は じめ に}

車両運動解析の分野では, 幅広い車両挙動を表現す るため精度の高いタイヤモデル開発が重要になってき ている.一般にタイヤモデルを構築するには，タイヤ 試験機で計測されたデータを用いるが，この結果には いくつかの問題が含まれる. 例えば, 試験機の入力条 件が実際の走行条件を反映しているかなどである.

この観点から, 著者らは実走行時の計測データから タイヤモデルを構築する手法を開発した ${ }^{(1)}$. 一方, 夕 イヤ特性計測時のタイヤ姿勢変化を車両が実際に走行 している状況でのタイヤの対地姿勢変化と同じように 試験機上で制御することで，より実走行結果に近い条 件下のタイヤ特性計測が可能なような手法が開発され ている(2).

しかし，これらの手法を用いても路面温度や走行中 のタイヤ表面温度などの他の条件が実走行状態のすべ てに適応しているとは考えにくい. 例えば,『釣り針 試験』と呼ばれる車両運動性能評価試験がある. 図 1 に実験時のハンドル角と車両重心位置における横加速

* 原稿受付 2004 年 7 月 21 日.

*1 正員, (株) 豊田中央研究所 CAE 推進室 (五 480-1192 愛知県 愛知郡長久手町).

*2 正員, ト $\exists$ 夕自動車(株) 車両技術本部第 2 車両技術部(画 471-8572 豊田市卜ヨ夕町 1).

*3 $ト$ ヨ夕自動車 (株) 車両技術本部第 2 車両技術部.

E-mail : mizuno@vdlab.tytlabs.co.jp
度の一例を示す.この図 1 に示されている第一ピーク 值 (車両挙動で見た場合, 横加速度の向きが反転する までに現れる横加速度の最大値) が車速や路面温度に よってどのように変化しているかを図 2 に示す.この 結果から見ると，路面温度が異なると同じ車速で試験 を行っても発生する横加速度が異なっている.これは, 路面温度の違いからタイヤ表面温度が変化し, その結 果タイヤ発生力も異なるために運動性能が変化したと 考えられる.

そこで本研究では, タイヤ表面温度とタイヤ発生力 の関係を定式化し, タイヤ表面温度の影響を考慮した タイヤモデルを開発する.特に, 近年車両運動解析で 用いられるようになった “Magic Formula” と呼ばれる タイヤモデルをべースに表面温度の影響を考虑できる 車両運動解析用タイヤモデルの解析を行い, このモデ ルの妥当性を実験結果との比較によって検証する.

また, 最後にこのモデルから車両運動にタイヤの 温度特性が与える影響をシミュレーションを用いて論 じる.

\section{2. 温度依存性を考虑したタイヤモデルについて}

今回考案したモデルは, タイヤ表面の温度変化を伝 熱方程式を用いて算出する関数と，この表面温度変化 の影響を考慮してタイヤ発生力を変化させることの 

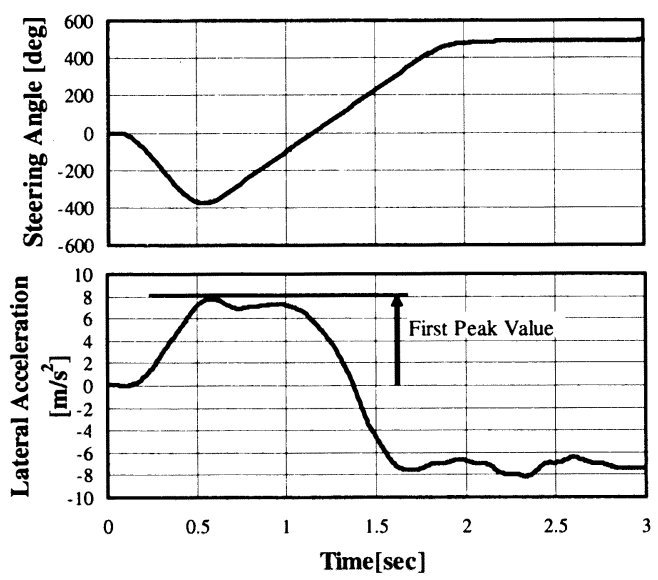

Fig. 1 The Example of Steering Angle and Lateral Acceleration in 'Fish-Hook Test'

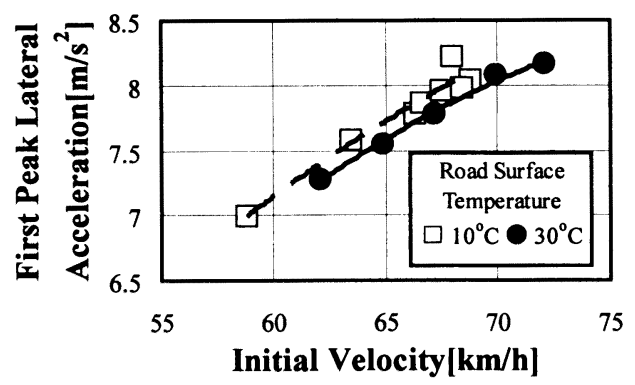

Fig. 2 The Test Results of the Relation between the Initial Vehicle Velocity and First Peak Value of Lateral Acceleration in Summer and Winter Season's Test

できる Magic Formula タイヤモデル ${ }^{(3)}$ から構成されて いる.

次節にこれら関数についての詳細を示す. なお, 数 式に用いられている記号の意味については文末の表 1 を, 座標系の定義については図 3 を参照のこと.

2.1 タイヤ表面温度の変化について タイヤ表 面の温度変化を表す熱力学モデルを求めるにあたって, タイヤにおける熱移動を以下のように仮定した.

・タイヤに発生する熱は主にトレッドで発生する

・タイヤからの放熱は主にトレッドで行われる

- 発熱と放熱が同一部位で同時に行われている

・トレッドの温度は一様である

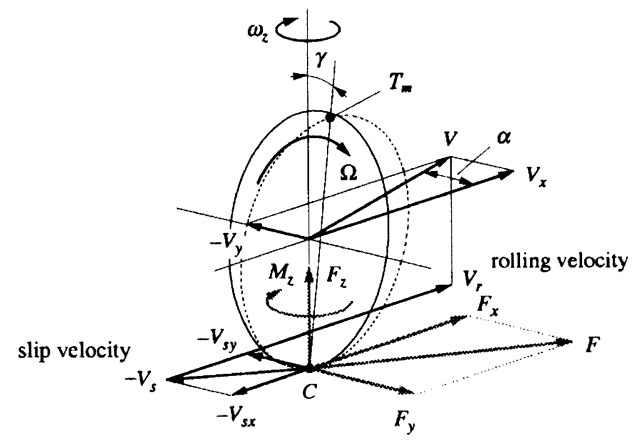

Fig. 3 Basic Quantities used in This Paper

これらからタイヤ表面温度変化は次の式で与えら れる.

$$
W \frac{d T}{d t}=q-\lambda A\left(T-T_{R}\right)
$$

次に，タイヤが地面に対して行う仕事すべてがタイ ヤの発熱になると仮定すると，

$$
\begin{aligned}
q & =\boldsymbol{F} \cdot \boldsymbol{V}_{s} \\
|\boldsymbol{F}| & =\sqrt{F_{x}^{2}+F_{y}^{2}} \\
\left|\boldsymbol{V}_{s}\right| & =\sqrt{V_{s x}{ }^{2}+V_{s y}{ }^{2}} \\
& =\sqrt{\left(V \cos \alpha-r_{e} \Omega\right)^{2}+V^{2} \sin ^{2} \alpha}
\end{aligned}
$$

となる. 式 (2) は $\alpha=0$ で, $q=F_{x} \cdot(V-r \omega)=F_{x} V S$ となり, $S=0$ で $q \approx F_{y} V \alpha$ となる. これらの式を用い ることで, タイヤ表面の温度変化が計算可能となる.

次に, 式 (1) に用いられているパラメータ $\lambda$ および $W$ の算出方法を考える.

2.1.1 $\lambda$ の算出方法 式(1)において, $\kappa=\lambda A / W$ としたうえで式を変形すると,

$$
\frac{d T}{d t}=\frac{q}{W}-\kappa\left(T-T_{R}\right)
$$

となる. ここで $q=0$ すなわちタイヤが地面に対して 行う仕事が 0 になると式 (6) は次のように変形される.

$$
\kappa=-\frac{d T}{d t} \cdot \frac{1}{T-T_{R}}
$$

この式から，火はタイヤの仕事が 0 でタイヤ表面の 温度変化がある条件下でタイヤ表面温度を計測するこ とで算出可能である. タイヤに加わる仕事が 0 でタイ ヤ表面温度が変化する条件を考えると, タイヤ表面を 大気温あるいは路面温度より高くして仕事 0 の状態で 転動させれば表面温度は徐々に低下するため, このよ うな条件を実験で作る必要がある.

例えば図 4 に示すようなスリップ角変化を転動時の タイヤに与える. タイヤの進行方向と転がり方向が一 
致しない，すなわちタイヤにスリップ角が与えられる と，タイヤは路面との閒にせん断力が発生する.その ため,タイヤ表面には式(2)より熱が蕃積されタイヤ 表面の温度上昇が起こる。

このようにタイヤ表面温度を上げた後，タイヤのス リップ角を0にして仕事を0にすれば，式 (6)よりタ イヤ表面から放熱されるため，タイヤ表面を冷やして いる状態となる。.この条件で温度変化を計測すれば は計測可能である。図 5 に計測結果を示す。なお，今 回は乗用車用タイヤ(サイズ:205/65R15) を用いて計測 を行った。

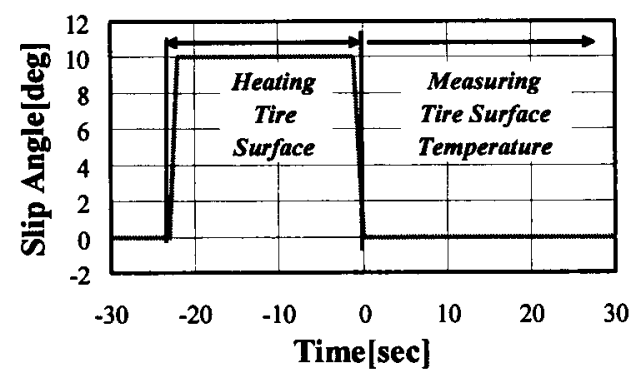

Fig. 4 Slip Angle Measuring the Parameter $K$ and $W$

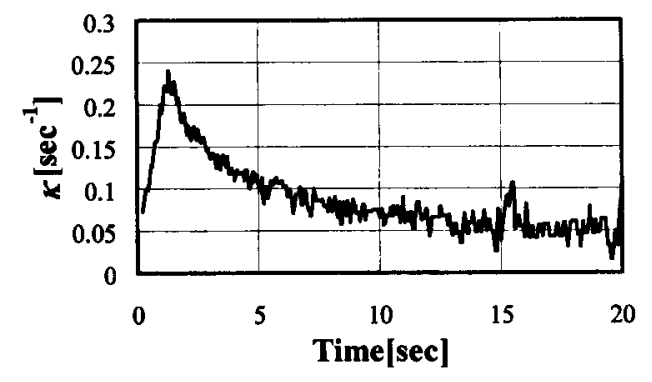

Fig. 5 Measured Results of $\kappa$ [Vertical Load:4600N]

火は時々刻々変化しているが, 今回のモデルで仮定 したタイヤのトレッドの温度が均一であるという条件 に比較的近い状態での計測結果を用いることから時間 的な変動が少なくなった状態 (図 5 中 10〜20秒)の平 均值を用いて $\boldsymbol{K}$ を求める.

なお，図 5 は直接 $\lambda$ を求めているわけではないが, 式(6)を解くために必要なパラメータは $\kappa$ およびWで あるため，今後はこのパラメータで式を解く.

2.1.2W の算出方法 式(1)を整理しなおすと

$$
W=\frac{q}{\frac{d T}{d t}+\kappa\left(T-T_{R}\right)}
$$

となる.ここで，火は前小節より算出され， $q$ は式 (2) 〜 (5) より $F_{x}, F_{y}, V_{s x}, V_{s y}$ を計測すれば算出できる. ま た, $d T / d t, T$ は非接触の赤外線放射温度計を用いるこ とでタイヤ表面温度を計測できる，以上の計測値を用 いることで $W$ は実験結果から算出可能である. 計測 はqが与えられかつ温度変化があればよいので，図4 のタイヤ表面を暖めるシーケンスの部分で計測すれば よい.

なお，タイヤの表面温度の計測は縤密に言うと路面 から離れた直後が最も高いと考えられる.また,タイ ヤの横断面 (回転方向に直角な断面) でみた場合にも 接触点によって異なると考えられる.そこで, 今回は 代表点として接地面のタイヤ回転軸を介して反対側の タイヤ幅力向の中央点の温度を計測している (図 $3 T_{m}$ 点).

図 6 にWの計測結果例を示す。この場合, タイヤ を右に切った場合 (図 4 でスリップ角プラス側のシー ケンス) と左に切った場合では，絶対值が同じスリッ プ角であっても発生するタイヤ横力の絶対值が同じに なるとは限らないため，算出された $W$ は図 6 のよう に異なる值を示す.

さらにW の值は前述の $\boldsymbol{\kappa}$ と同様に, モデルを導く ときの仮定から図 6の-15〜-2 秒のデータの平均值を 用いている.

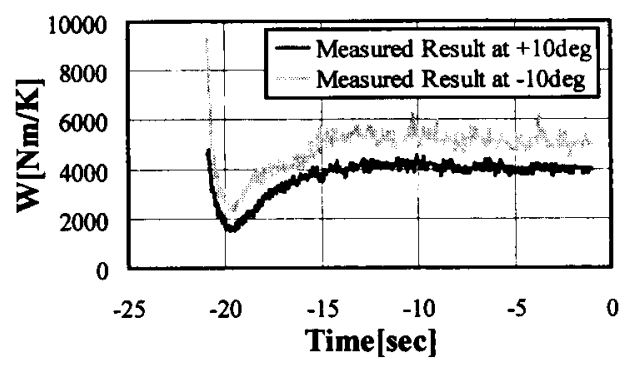

Fig. 6 Measured Results of $W$ [Vertical Load:4600N]

同様に前後力を発生させる場合においてもブレーキ 側・駆動側で絶対值が同じスリップ率であっても発生 する前後力の絶対値が異なることから, 式 8 で求めた 值は図 6 と同様に前後で異なる結果となる. そこで前 後方向の計測結果から求めた $W$ も二つの平均値を用 いることとした.

しかしながらタイヤの部材を考えると，タイヤの左 右力・前後力ともに同じ部位で発热・蓄熱を行ってい ることから，左右力から算出した $W$ と前後力から算 出した $W$ の平均值をタイヤの蓄熱係数 $W$ として扱う こととした. 
2.2 Magic Formula を用いた温度変化を考慮した タイヤ発生カ タイヤ力のモデル化を行う場合, ス リップ角が 0 でスリップ率だけが変化している場合, あるいはその逆のスリップ角が変化してスリップ率が 0の条件下，すなわち Pure Slip Condition での特性を 求め, この特性からこれら二つの条件が共に0ではな い, すなわち Combined Slip Condition での特性をモ デル化するのが一般的である.

今回作成した温度特性を考慮したモデルについても, 同様の方法にてモデル化を行う.

最初に, Pure Slip 状態を表す Magic Formula タイヤ モデル ${ }^{(3)}$ は, 次の式で表される.

$$
\begin{gathered}
F_{i 0}(p)=D_{i} \sin \left[C_{i} \tan ^{-1}\left\{B_{i} p-E_{i}\left(B_{i} p-\tan ^{-1}\left(B_{i} p\right)\right)\right\}\right] \\
+S_{v i} \\
\quad p= \begin{cases}\alpha+S_{h x} & \text { if } i=x \\
S+S_{h y} & \text { if } i=y\end{cases}
\end{gathered}
$$

そこで, タイヤ表面温度変化によって Magic Formula の $D_{i}$ (発生力の最大值を表す係数) と $K_{i}=B_{i} \cdot C_{i} \cdot D_{i}(x=$ 0 での曲線の傾き) が変化すると仮定すると, 式 (9) は 次のようになる。

$$
\begin{gathered}
F_{i 0}(p, T)=D_{i}(T) \sin \left[C _ { i } \operatorname { t a n } ^ { - 1 } \left\{B_{i}(T) p-E_{i}\left(B_{i}(T) p\right.\right.\right. \\
\left.\left.\left.-\tan ^{-1}\left(B_{i}(T) p\right)\right)\right\}\right]+S_{v i} \\
K_{i}(T)=B_{i}(T) \cdot C_{i} \cdot D_{i}(T)
\end{gathered}
$$

これらの式より， $D_{i}$ と $K_{i}$ のタイヤ表面温度に対す る変化の度合いを計測すれば式 (11) を求めることが できる，以下にそれぞれの算出方法と結果を示す.

2.2.1 $D_{i}$ の算出方法 $D_{i}$ は先に示したように発 生力の最大值を示寸係数となる. そこで, 前後方向は ブレーキ力または加速力の最大值を発生させるスリッ プ率で, 左右方向は横力最大值のスリップ角にて固定 し, そのときのタイヤ力の変化とタイヤ表面温度との 関係を調べることで， $D_{i}$ が算出できる.

まず $D_{i}$ に関して前後方向のパラメータ $D_{x}$ および 左右方向 $D_{y}$ を求めるとそれぞれ図 7,8 のようになる. 前後に関しては試験機の都合上减速側のみを計測した. また, 図 8 では右と左では発生する力の向きが逆にな るが, タイヤ表面温度に対する横力最大值の感度を示 すために力の絶対值を表示している.

得られた結果より， $D_{i}$ はタイヤ表面温度に対して 1 次関数で近似できることから，

$$
D_{i}(T)=D_{i 0}\left\{1+a_{i} \cdot\left(T-T_{0}\right)\right\}
$$

とした。

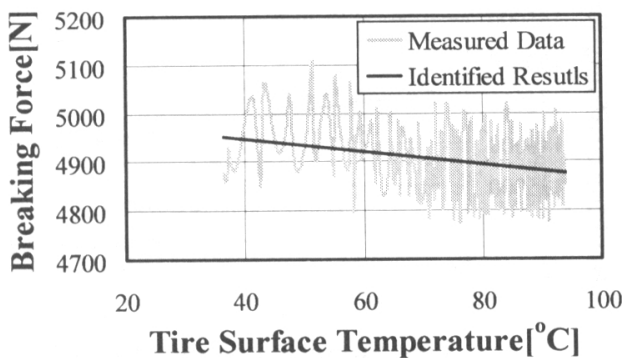

Fig. 7 Measured Data and Identified Results of $D_{x}(T)$ [Vertical Load:4600N]

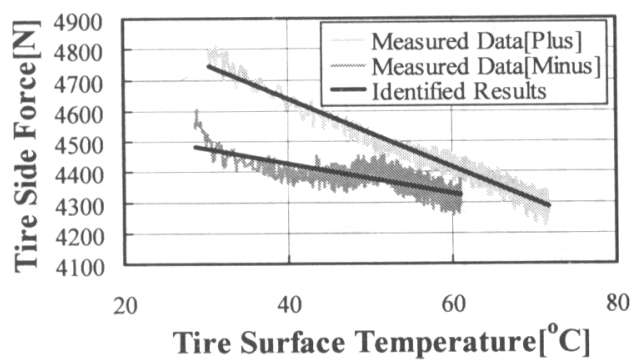

Fig. 8 Measured Data and Identified Results of $D_{y}(T)$ [Vertical Load:4600N]

ここで $T_{0}$ は Base となる Magic Formula の Parameter を算出するために実験を行った時の，タイヤ表面温度 の平均值である。

但し，図 8 の場合それぞれ右側・左側に切った場合 で得られた結果が異なっている. そこで，右切り・左 切りで得られた計測結果から近似した 1 次関数の結果 を平均化することで，左右方向の温度依存性の係数を 求めている.

2.2.2 $K_{i}$ の算出方法 $K_{i}$ についても前後方向な らびに左右方向の值を調べる必要がある。ここでは前 後に関しては減速側のスリップ率 0.01 での前後力を, 左右に関しては $\pm 1[\mathrm{deg}]$ の横力の温度変化による影響 をもとに算出する.

図 9 と 10 に前後・左右方向の $K_{x}, K_{y}$ の計測結果を 示す. $K_{y}$ に関しては, 左右それぞれのスリップ角 1 度 における計測結果を示している.

得られた結果より, $K_{i}$ もタイヤ表面温度に対して 1 次関数で近似できることがわかる.よって，

$$
K_{i}(T)=K_{i 0}\left\{1+b_{i} \cdot\left(T-T_{0}\right)\right\}
$$

とした.

但し, 図 10 に示されるように, 左右の $K_{y}$ について 


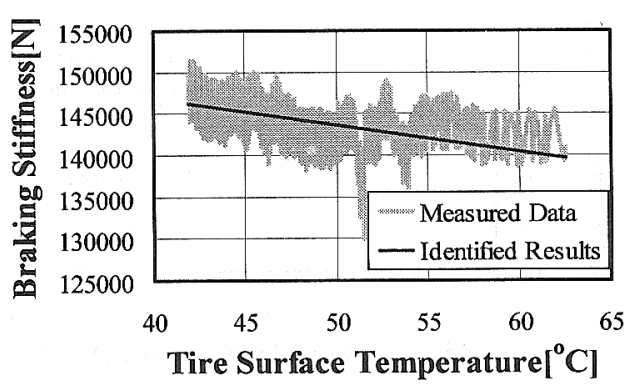

Fig. 9 Measured Data and Identified Results of $K_{x}(T)$ [Vertical Load:4600N]

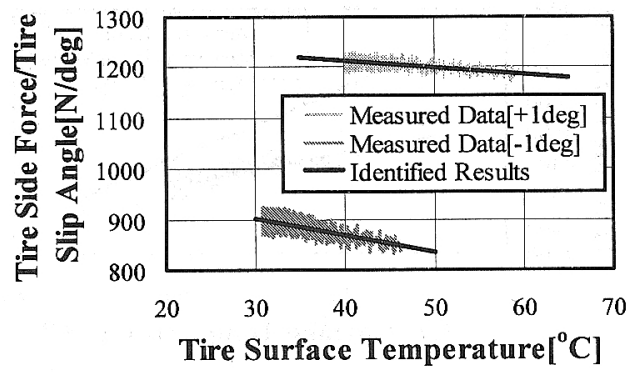

Fig. 10 Measured Data and Identified Results of $K_{y}(T)$ [Vertical Load:4600N]

は值が異なっていることより， $D_{y}$ と同じように，得ら れた 1 次関数近似の結果を平均化した值で $K_{y}$ を求め ている.

2.2.3 Combined Slip 時の特性 Magic Formula における Combined Slip 時のタイヤ特性を表す式を示 すと次のようになる.

$$
\begin{aligned}
& F_{x}\left(\alpha, S, F_{z}\right)= F_{x 0}\left(S, F_{z}\right) \cdot G_{x \alpha}\left(\alpha, S, F_{z}\right) \\
& F_{y}\left(\alpha, \gamma, S, F_{z}\right)= F_{y 0}\left(\alpha, \gamma, F_{z}\right) \cdot G_{y S}\left(\alpha, \gamma, S, F_{z}\right) \\
&+S_{V y S} \\
& こ こ に, \text { 式 }(11) \text { を代入すると } \\
& F_{x}\left(\alpha, S, F_{z}, T\right)= F_{x 0}\left(S, F_{z}, T\right) \cdot G_{x \alpha}\left(\alpha, S, F_{z}\right) \\
& F_{y}\left(\alpha, \gamma, S, F_{z}, T\right)= F_{y 0}\left(\alpha, \gamma, F_{z}, T\right) \cdot G_{y S}\left(\alpha, \gamma, S, F_{z}\right) \\
&+S_{V y S}
\end{aligned}
$$

すなわち, Combined Slip 時の温度依存性は Pure Slip 状態を表すタイヤモデルを用いて表現することが可能 となる。

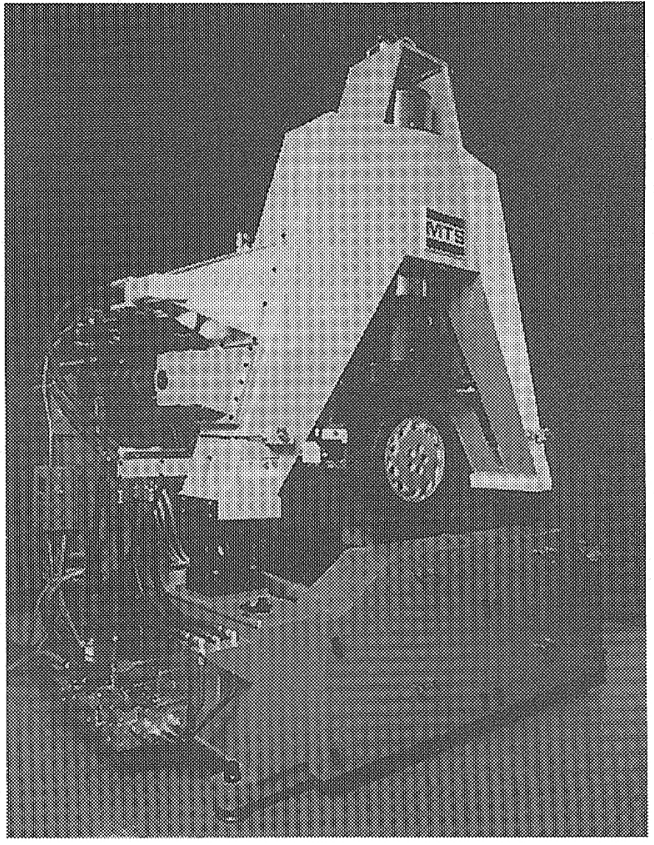

Fig. 11 Tire Test Machine to Measure Tire Force and Surface Temperature

\section{3. 開発したタイヤモデルの検証}

タイヤの定常特性を計测し，それと異なるスリップ 角速度およびスリップ率の変化速度を試験機で与え, 実験結果とシミュレーション結果を比較する方法でモ デルの検証を行った. 今回はMTS 社製フラットベルト タイヤ試験機 (図 11 参照) を用いてベルト速度 $60 \mathrm{~km} / \mathrm{h}$ で実施した。試験機の特性については表 2 に示す。

なお，今回の試験機には非接触の赤外線表面温度計 は組み込まれていないため，タイヤ接触面からみてス ピンドル軸の反対側の温度を測るように表面温度計の センサを油圧シリンダ (図 11 中タイヤ上部の黒い部 分)の最下端に下向きに取り付けた.

$3 \cdot 1$ 前後力に関するタイヤモデルの検証結果＼cjkstart前 後力の特性に関して温度依存性を考慮したモデルが実 際の特性をどの程度模擬できているかを調べるため, Magic Formula のパラメータを求めたあとに異なる計 測条件でタイヤ試験を行い，このときの実験条件をモ デルの入力条件としてシミュレーションを実施した.

なお，シミュレーションの計算においてはタイヤ発 生力の応答遅れを考慮するために, 緩和長を用いた一 時遅れ系の発生力遅れ機構を加えている．緩和長の長 さは，前後方向・横方向とも $0.6 \mathrm{~m}$ として計算を行った. 
ここで述べているタイヤ発生力の遅れ機構は, タイ ヤが突然スリップ角あるいはスリップ率を生じたとき にタイヤの接地面と回転面あるいは接地面の前端と後 端でずれが生じるため, 急激に力を発生することがで きずタイヤの転動と共に力を生じていく状況を考えて いる、なおこれらの考え方の詳細についてはたとえ ば文献 ${ }^{(4)}$ を参照のこと.

図 12 に試験機による計測パターンを示す，定常特 性を求める，すなわち Magic Formula のパラメータを 求めるための計測パターンは図中 “ $2 \mathrm{sec}$ ”でされた パターンである.ここで求めた定常特性モデルを用い て, 図中 “8sec” で示されたパターンでの計測結果と シミュレーション結果を比較する.

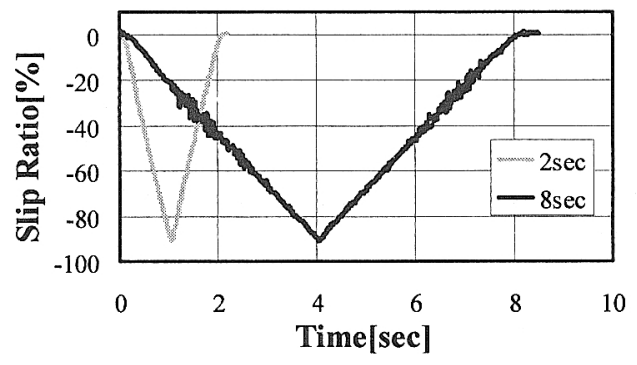

Fig. 12 Measurement Sequence for Longitudinal Force Tire Model and Comparison Between Measured Data and Simulation Results

図13から15 にシミュレーション結果と実験結果の 比較を示す. 図 13 は開発したモデルと従来モデルと のスリップ率に対する発生力の違いを, 図 14 は実験 結果と開発したモデルのスリップ率に対する発生力を, 図 15 は実験結果と開発したモデルのスリップ率に詨 するタイヤ表面温度をそれぞれ示す。

シミュレーション結果を比較すると従来モデルは温 度依存性が考慮されていないことから，スリップ率の 変化に対して制動力の変動の大きなスリップ率-10〜 $0[\%]$ 程度の領域でタイヤ発生力の遅れ機構による七 ステリシスが見られる。しかし，スリップ率が-10[\%] より小さな領域においてはスリップ率が減少する行程 と増加する行程で発生力の差はほとんど見られない.

これに対して開発したモデルにおいては，タイヤ表 面の温度変化に伴う発生力の違いが現れ，特にスリッ プ角の絶対值が小さくなる状況では従来のモデルの結 果に対して $15 \%$ 程度発生力が小さくなっている．これ を実験結果と比較すると，ピークの大きさが若干異な るものの, スリップ率の絶対值が増加する場合と減少

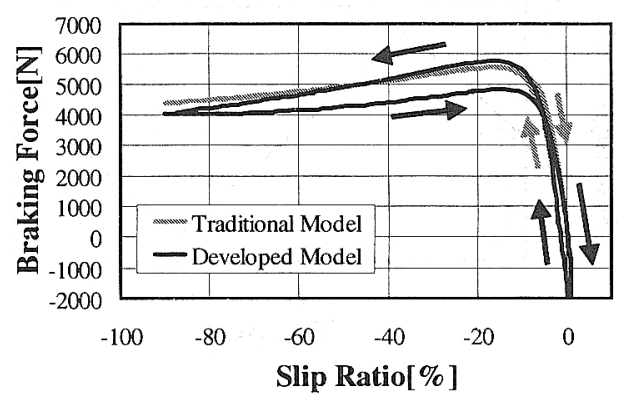

Fig. 13 Simulation Results of Slip Ratio vs. Braking Force using Traditinal Model and Developed Model[Vertical Load:4600N]

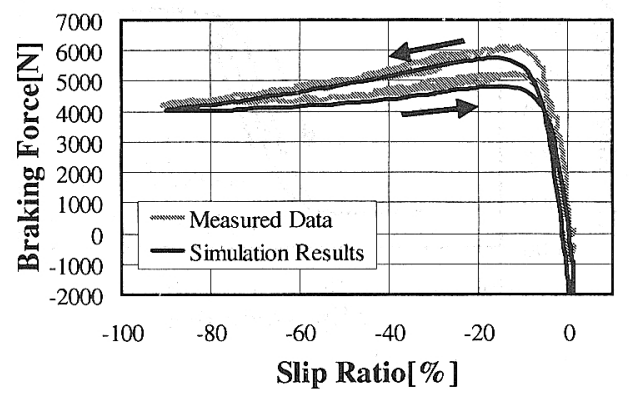

Fig. 14 Measured Data and Simulation Results of Slip Ratio vs. Braking Force[Vertical Load:4600N]

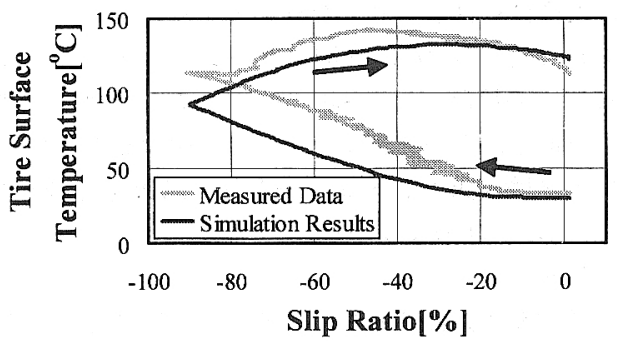

Fig. 15 Measured Data and Simulation Results of Slip Ratio vs. Tire Surface Temperature[Vertical Load:4600N]

する場合のタイヤ力の変化はほぼ同じとなっている. 同様にタイヤ表面温度とスリップ率の関係も実験結果 とほぼ同じ傾向を示しており，今回開発したモデルは 実験結果にほぼ一致したモデルといえる. 


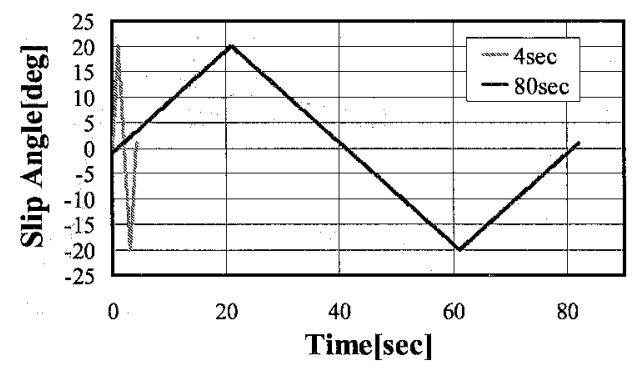

Fig. 16 Measurement Sequence for Lateral Force Tire Model and Comparison Between Measured Data and Simulation Results

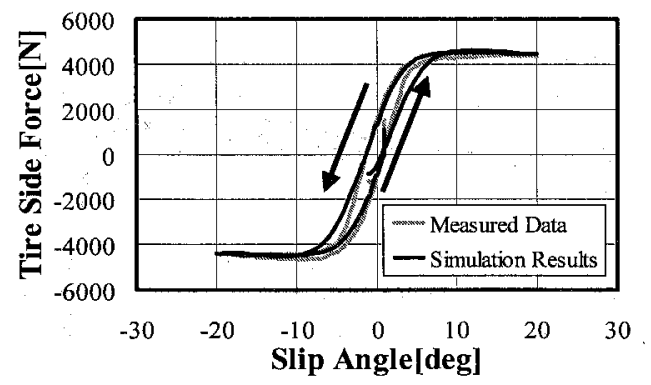

Fig. 17 Measured Data and Simulation Results of Slip Angle vs. Lateral Force[Vertical Load:4600N]

3.2 横カに関するタイヤモデルの検証結果 次 に，温度依存性を考慮した横力モデルに関して実験検 証を行った．図16に計測パターンを示す．今回横力 のモデルの検証では，図中"80 sec"でタイヤの定常特 性を計測し，そのモデルを用いて図中"4sec”のパター ンでの試験結果とシミュレーション結果を比較した.

図 17 および 18 に計測結果とシミュレーション結果 の比較を示す.

タイヤ発生力に関しては, 前後力と同じくピーク付 近での力の出方に若干の差が見られるが，最大值の值 とその前後での横力の変化の状況は害験結果とよく一 致している、タイヤ表面温度の变化についても变化の 傾向がほぼ一致しており, 今回開発したモデルの妥当 性を示すことが出来た.

\section{$3 \cdot 3$ 実験結果と計算結果の違いに関する考察 前} 後力および横力の最大值発生状況が実験と計算で若干 異なったこと, ならびにタイヤ表面温度の变化が実験 と計算で若干異なっていることに関して考察を加える.

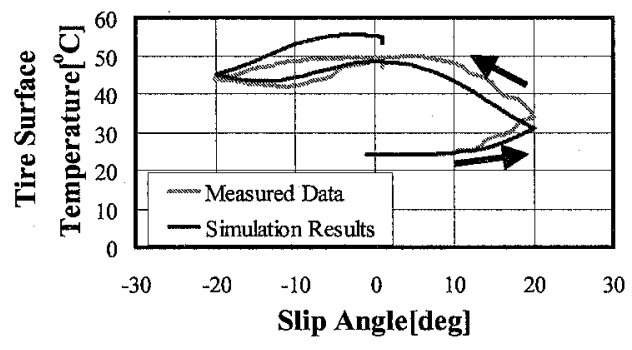

Fig. 18 Measured Data and Simulation Results of Slip Angle vs. Tire Surface Temperature[Vertical Load:4600N]

まず，今回のシミュレーションでは緩和長が一定で あるという仮定でシミュレーションを実施した．しか し, 緩和長はスリップ角やスリップ率の変化に伴って 変化していることが実験で求められている(5). 実験結 果では, スリップ角やスリップ率の絶対值が小さくな るほど緩和長が大きくなっていることから，今回のシ ミュレーションにおいてもスリップ率やスリップ角が 大きくなるとともに緩和長を小さくするとピーク付近 での前後力や横力のスリップ角に対する変化率が大き くなると考えられる.

以上の点から，シミュレーションを実施する際の条 件として今回のような比較的スリップ率変化やスリッ プ角変化の大きな状況を取り扱う場合においては，緩 和長も変化させて特性を求める必要があると考学る。

次に，スリップ角の正負に伴って変化しているタイ ヤ表面温度の变化について考える.実験結果を見ると， スリップ角が正の側で温度が高めに，負の側で低めに 出る傾向が見られる。

今回実験を行ったタイヤ試験機が置かれている環境 を見ると，スリップ角が負になる側から冷却風が当た るような構造となっており，今回はこの風の影響を受 けてスリップ角の正負で温度上昇の傾向が変わったと 推測される.

\section{4. まと め}

本稿では, 気温や路面温度違いによる車両運動性能 差を議論するために，新しいタイヤモデルの提案を 行った，本研究で得られた結果を以下にまとめる.

- Magic Formula と呼ばれる車両運動解析用タイヤ モデルをベースに，温度依存性を考虑したタイヤ モデルを棈築した

・棈築したタイヤモデルのパラメータを実験的に求 
める手法を開発した

・このモデルを用いてタイヤ試験法を変更してタイ ヤの特性を計測した結果と比較したところ，ほぼ 一致した特性を得ることができた

Table 1 Notation

\begin{tabular}{|c|c|}
\hline Symbol & Description \\
\hline$A$ & Contact Area of Tread \\
\hline$F_{x}$ & Longitudinal Force \\
\hline$F_{y}$ & Lateral Force \\
\hline$F_{i 0}$ & $\begin{array}{l}\text { Longitudinal or Lateral Force under Pure Slip } \\
\text { Condition }\end{array}$ \\
\hline$G_{x \alpha}$ & $\begin{array}{l}\text { Weighting Function for } F_{x} \text { describing the } \\
\text { effect of slip angle }\end{array}$ \\
\hline$G_{y S}$ & $\begin{array}{l}\text { Weight Function for } F_{y} \text { describing the effect } \\
\text { of longitudinal slip ratio }\end{array}$ \\
\hline$S$ & Longitudinal Slip Ratio $\left(=-V_{s x} / V_{x}\right)$ \\
\hline$S_{h i}$ & Holizontal Shift Value \\
\hline$S_{v i}$ & Vertical Shift Value \\
\hline$S_{V y S}$ & $\begin{array}{l}\text { Vertical Shift for } F_{y} \text { describing the effect of } \\
\text { longitudinal slip ratio }\end{array}$ \\
\hline$T$ & Tire Surface Temperature \\
\hline$T_{R}$ & Road Surface Temperature \\
\hline$T_{0}$ & $\begin{array}{l}\text { Average of Tire Surface Temperature during } \\
\text { Measuring Steady State Tire Characteristics }\end{array}$ \\
\hline$V$ & Vehicle Velocity \\
\hline$V_{s}$ & Vehicle Slip Velocity \\
\hline$W$ & Heat Capacity \\
\hline$a_{i}$ & $\begin{array}{l}\text { Variation of Tire Peak Force with Tire Surface } \\
\text { Temperature }\end{array}$ \\
\hline$b_{i}$ & $\begin{array}{l}\text { Variation of Tire Stiffness with Tire Surface } \\
\text { Temperature }\end{array}$ \\
\hline$i$ & Subscripts $x$ or $y$ \\
\hline$q$ & Heat Flux \\
\hline$r_{e}$ & Effective Free Rolling radius \\
\hline$\alpha$ & Slip Angle \\
\hline$\lambda$ & Thermal Conductivity \\
\hline$\Omega$ & Rolling Angular Velocity \\
\hline
\end{tabular}

Table 2 Tire Test Machine Specification

\begin{tabular}{|c|c|}
\hline Maximum tire size & $910 \mathrm{~mm}$ \\
Maximum speed & $\pm 250 \mathrm{~km} / \mathrm{h}$ \\
Maximum vertical force & $25,000 \mathrm{~N}$ \\
Maximum longitudinal force & $\pm 10,000 \mathrm{~N}$ \\
Maximum lateral force & $\pm 15,000 \mathrm{~N}$ \\
Maximum over turning torque & $\pm 10,000 \mathrm{Nm}$ \\
Maximum aligning torque & $\pm 2,000 \mathrm{Nm}$ \\
Maximum spindle torque & $\pm 2,800 \mathrm{Nm}$ \\
Maximum slip angle & $\pm 30 \mathrm{deg}$ \\
Inclination angle & $-12 \mathrm{deg}$ to $+45 \mathrm{deg}$ \\
\hline
\end{tabular}

(1) Mizuno, M., Takahashi, T. and Hada, M. : Magic Formula Tire Model Using the Measured Data of a Vehicle Running on Actual Road, AVEC '98, September 1998, Nagoya, Japan.

(2) Oosten, J.J.M. van et al. : TIME, Tire Measurements, Forces and Moments, Final report, February 1999, EC DG XII, Standards, Measurements \& Testing, TNO, Delft, Netherlands.

(3) Bakker, E., Nyborg, L., and Pacejka, H.B. : Tyre Modelling for Use in Vehicle Dynamics Studies, SAE Paper No. 870495, 1987.

(4) 安部正人 : 自動車の運動と制御, 山海堂, 1992

(5) Higuchi, A. : Transient response of tyres at large wheel slip and camber, Dissertation, TU Delft, 1997. 